\title{
Conseil juridique
}
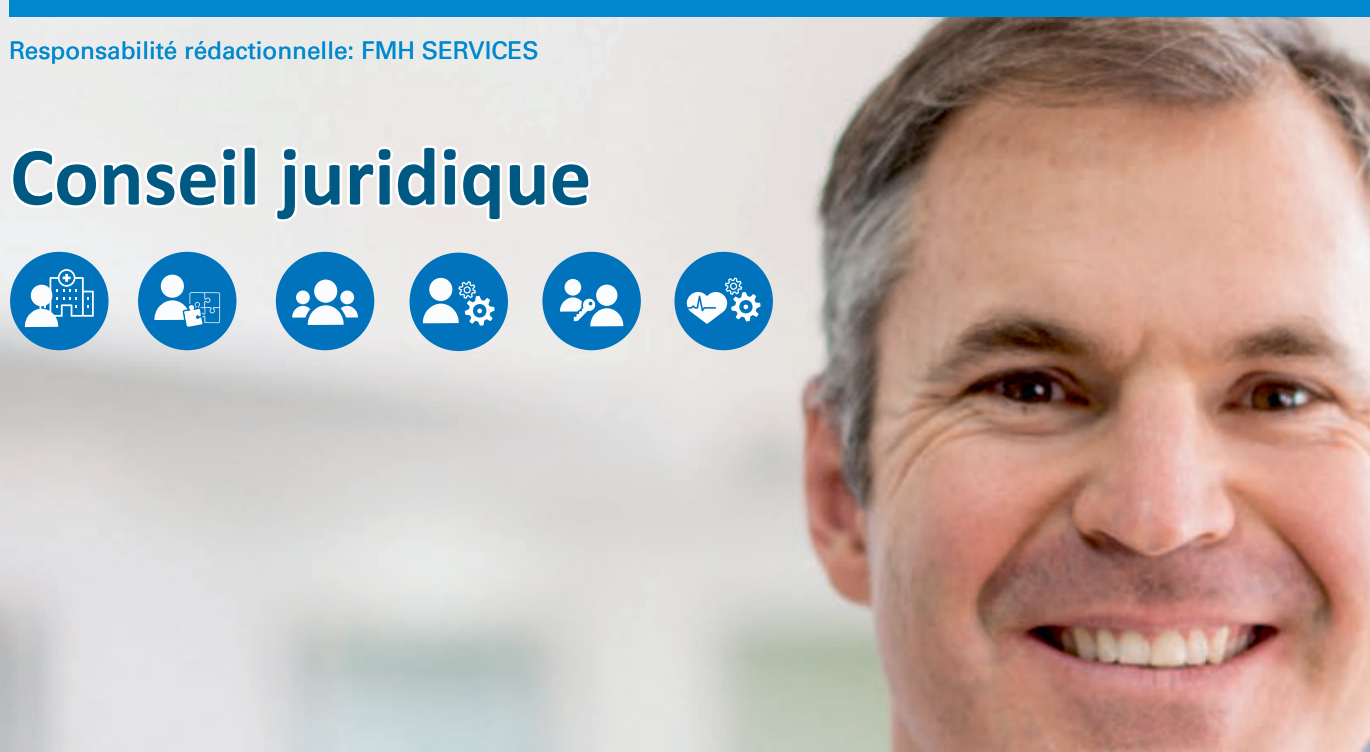

En tant que société de services destinée aux médecins qui exercent en Suisse, nous vous proposons:

- Elaboration et négociation de contrats

- Conseil sur la forme juridique

- Droit du travail et autorisations

\section{CONSEIL JURIDIQUE}

\section{† FMHSERVICES}

Vous pouvez prendre contact avec nous sans aucune obligation par téléphone ou courrier électronique ou en nous retournant le talon-réponse par fax ou par la Poste. Nous vous contacterons.

Prénom / nom

Adresse

NPA / lieu

Téléphone privé / prof.

Atteignable de préférence vers

CONSULTING

FMH Consulting Services AG

Avenue d'Ouchy 66, 1006 Lausanne

Tél. 0219224435

mail@fmhconsulting.ch - www.fmhservices.ch 